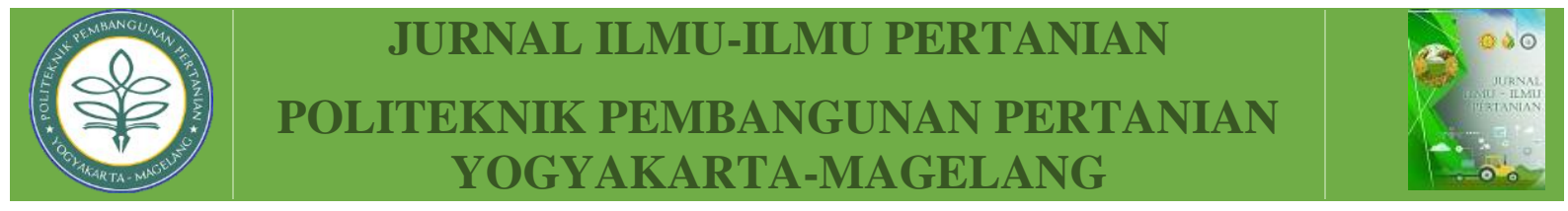

\title{
PENGARUH POLA TANAM TERHADAP PERTUMBUHAN DAN HASIL KENTANG DI WILAYAH DATARAN TINGGI DIENG JAWA TENGAH
}

\author{
Miranti Dian Pertiwi ${ }^{1}$, Intan Gilang Cempaka ${ }^{2}$ \\ ${ }^{1}$ Balai Pengkajian Teknologi Pertanian Jawa Tengah, Ungaran, 50552 \\ 2Balai Pengkajian Teknologi Pertanian Jawa Tengah, Ungaran, 50552
}

Received

Accepted

Published

Copyright Notice

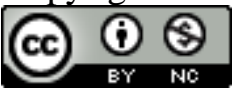

: March $12^{\text {th }}, 2021$

: $\quad$ May $17^{\text {th }}, 2021$

: June $9^{\text {th }}, 2021$

: Authors retain copyright and grant the journal right of first publication with This work is licensed under a Creative Commons Attribution-Non Commercial 4.0 International License.

ABSTRAK: Peluang peningkatan produktivitas kentang di Jawa Tengah masih sangat terbuka, mengingat produktivitasnya belum maksimal. Salah satu penyebabnya diduga adalah frekuensi penanaman kentang yang terlalu sering, yaitu dua sampai tiga kali dalam satu tahun dengan pola kentang-kentang-kentang atau sayuran lain-kentang-kentang. Oleh karena itu dilakukan percobaan dengan tujuan mengidentifikasi perbedaan pertumbuhan dan hasil kentang yang ditanam di tiga wilayah dataran tinggi Dieng yang memiliki pola tanam yang berbeda dalam setahun. Percobaan disusun dengan rancangan petak terbagi, perbedaan pola tanam di tiga lokasi sebagai petak utama (Wonosobo 2 kali tanam kentang/tahun, Banjarnegara 3 kali tanam kentang/tahun, Pekalongan 1 kali tanam kentang/tahun) dan tiga varietas sebagai anak petak (Granola L, Granola K, Tedjo-MZ) yang disusun dalam tiga ulangan. Hasil penelitian menunjukkan bahwa pertumbuhan tiga varietas lebih optimal di lokasi Pekalongan dibanding di Wonosobo dan Banjarnegara. Demikian juga dengan komponen hasil yaitu bobot segar umbi per tanaman dan produktivitas umbi per hektar menunjukkan bahwa di lokasi Pekalongan nyata lebih tinggi dibanding di Wonosobo dan Banjarnegara. Hasil percobaan ini memberikan informasi awal bahwa perbedaan pola tanam atau intensitas tanaman kentang dalam setahun berpengaruh terhadap pertumbuhan dan hasil yang diperoleh. Pola tanam kentang satu kali setahun menunjukkan pertumbuhan dan hasil yang lebih baik dibanding pola tanam kentang dua dan tiga kali setahun.

Kata kunci: Pola tanam kentang, Granola L, Granola K, Tedjo-MZ, Jawa Tengah.

\footnotetext{
*mdpmiranti@gmail.com ${ }^{l}$
} 
ABSTRACT: The opportunity to increase potato productivity in Central Java is still open widely because its productivity is not maximized. It is allegedly because of the very intensive potato cultivation which is two to three times a year. Therefore, an experiment was carried out aimed to identify the differences in the growth and yield of potatoes grown in the Dieng plateau areas that had different cropping patterns in a year. The experiment was arranged with a Split Plot design, different cropping pattern at three locations as the main plot (Wonosobo with two times potato plants per year, Banjarnegara with three times potato plants per year, and Pekalongan with one time potato plants per year) and three varieties as subplots (Granola L, Granola K, Tedjo-MZ) arranged in three replications. The results showed that the growth of the three varieties was more optimal in the Pekalongan location than in Wonosobo and Banjarnegara. Likewise, the yield components, that were tuber fresh weight per plant and tuber productivity per hectare, showed that the Pekalongan location was significantly higher than in Wonosobo and Banjarnegara. The results of this experiment provide preliminary information that differences in cropping patterns or the intensity of potato cultivation in a year affect its growth and yields. The planting pattern of potatoes once a year showed better growth and yields than the cropping pattern of potatoes two and three times a year.

Keywords: Potato cropping pattern, Granola L, Granola K, Tedjo-MZ, Central Java.

\section{PENDAHULUAN}

Jawa Tengah merupakan produsen kentang nasional terbesar kedua setelah Jawa Barat, dengan sentra pertanaman di wilayah dataran tinggi Dieng di Kabupaten Banjarnegara dan Wonosobo (Subhan dan Asandhi, 1998). Lutaladio et al. (2009) dan Prabaningrum et al., (2014) melaporkan bahwa dataran tinggi di daerah Dieng memiliki iklim sejuk dan tanah berdrainase bagus sehingga sesuai untuk budidaya tanaman kentang. Wilayah tersebut memenuhi kriteria penting yaitu dari aspek suhu udara yang rendah antara $10-25^{\circ} \mathrm{C}$ dan kondisi tanah yang gembur. Dipertegas oleh Hamdani (2009) bahwa dataran tinggi yang optimal bagi pertumbuhan dan perkembangan tanaman kentang yaitu antara 1000 - 2000 m dpl. Selanjutnya Londhe (2016) juga melaporkan bahwa karakteristik tanah yang dibutuhkan tanaman kentang agar dapat tumbuh dengan baik yaitu tanah yang mempunyai solum dalam, mempunyai kandungan bahan organik cukup tinggi, dengan drainase baik. Tekstur tanah yang sesuai yaitu tanah liat yang gembur atau debu berpasir dengan $\mathrm{pH}$ berkisar antara 5 sampai 6,5 .

Luas pertanaman kentang di Jawa Tengah mencapai 16.938 ha, dengan areal terluas yaitu di Kabupaten Banjarnegara 7.511 ha atau $44,34 \%$ dan berikutnya adalah Kabupaten Wonosobo dengan luas 3.088 ha atau 8,23\% (BPS, 2012). Kontribusi Jawa Tengah terhadap produksi kentang nasional sebesar $25,84 \%$ namun demikian rerata produktivitasnya masih sangat rendah, yaitu 15,62 t/ha, lebih rendah dari produktivitas kentang di Jawa Barat yaitu 20,21 t/ha (Pusat Data dan Sistem Informasi Pertanian, 2015).

Banyak faktor yang mempengaruhi produktivitas suatu tanaman, antara lain pengelolaan tanaman oleh petani seperti pola tanam, rotasi tanaman, rotasi varietas dan sistem pertanaman yang dilakukan dalam setahun (Chen et al. 2015). Faktor pengelolaan ini akan mempengaruhi faktor lingkungan tumbuh (E) menyangkut aspekaspek abiotik seperti kesuburan tanah baik secara kimiawi dan fisika tanah, iklim mikro 
yang terbentuk di suatu wilayah. Selain itu juga terdapat faktor lingkungan biotik antara lain mikrobiologi tanah yang dapat mempengaruhi keseimbangan hara tanah dan keberadaan organisme pengganggu tanaman seperti hama, jamur, bakteri dan virus, keberadaannya sangat dipengaruhi oleh kebiasaan pengelolaan tanaman yang dilakukan oleh petani.

Mengingat produktivitas kentang di Jawa Tengah yang belum maksimal dan pentingnya posisi Jawa Tengah bagi pemenuhan kebutuhan kentang konsumsi di Indonesia, maka peluang untuk meningkatkan produktivitas kentang di jawa Tengah masih sangat terbuka. Berdasarkan kondisi tersebut maka dilakukan percobaan untuk mengetahui perbedaan pertumbuhan dan hasil kentang yang ditanam di tiga wilayah dataran tinggi Dieng yang memiliki pola tanam atau intensitas penanaman kentang yang berbeda dalam setahun. Varietas yang digunakan adalah varietas unggul jenis kentang sayur yang paling diminati oleh pasar baik lokal maupun nasional yaitu Granola L, Tedjo-MZ, dan Granola K. Varietas Granola L merupakan varietas kentang yang sudah lama berkembang di Indonesia dan menjadi varietas kentang yang paling diminati oleh masyarakat sampai saat ini. Tedjo-MZ adalah varietas unggul nasional yang baru dirilis pada tahun 2016 yang sebelumnya merupakan varietas lokal di Kabupaten Banjarnegara. Granola K merupakan varietas unggul yang awalnya merupakan varietas lokal di wilayah Malang, Jawa Timur.

\section{METODE}

Percobaan dilakukan di tiga lokasi yaitu di Desa Serang Kecamatan Kejajar, Wonosobo pada ketinggian 1500 mdpl, Desa Batur, Kecamatan Batur, Banjarnegara pada ketinggian 1600 mdpl, dan Desa Gumelem,
Kecamatan Petungkriyono, Pekalongan pada ketinggian 1650 mdpl. Materi utama percobaan adalah benih kentang yang berasal dari umbi. Benih umbi yang digunakan merupakan G3 berasal dari petani penangkar di Banjarnegara dan Malang.

Percobaan ini dirancang dengan rancangan petak terbagi yaitu lokasi sebagai petak utama terdapat tiga lokasi sebagai aras (Wonosobo, Banjarnegara dan Pekalongan). Selanjutnya varietas sebagai anak petak dengan tiga varietas sebagai aras (Granola 1, Granola K dan Tedjo-MZ), dan disusun dalam tiga ulangan. Percobaan dilakukan pada musim kemarau Juni - September atau musim tanam ke-3. Luas lahan percobaan di masing-masing lokasi yaitu $1000 \mathrm{~m}^{2}$. Jarak tanam yang digunakan yaitu 35 x $70 \mathrm{~cm}$. Pemupukan diberikan berdasarkan rekomendasi SOP Budidaya Kentang di Kabupaten Banjarnegara yaitu pupuk kandang ayam 25 ton/ha atau $850 \mathrm{~g} /$ tanaman, 700kg/ha NPK phonska, $110 \mathrm{~kg} / \mathrm{ha}$ SP36 dan $140 \mathrm{~kg} / \mathrm{ha} \mathrm{KCl}$.

Pengamatan yang dilakukan meliputi pengamatan karakteristik tanah dengan pengambilan sampel tanah dan dilakukan analisis di laboratorium. Selanjutnya dilakukan pengamatan pola tanam dalam setahun dengan metode wawancara langsung dengan petani. Pengamatan terhadap tanaman dilakukan pada akhir fase vegetatif cepat dan memasuki fase pembentukan umbi yaitu 50 hst dan pada saat panen. Panen dilakukan saat tanaman sudah memasuki umur masak fisiologis yaitu 100 hari untuk Granola L dan 120 hari untuk Granola K dan Tedjo MZ. Parameter yang diamati meliputi variabel pertumbuhan yaitu tinggi tanaman, jumlah cabang, diameter batang dan variabel komponen hasil yaitu jumlah umbi, bobot satuan umbi, dan bobot segar umbi per tanaman serta produktivitas umbi per hektar.

Data yang telah diamati kemudian 
tabulasi dalam format excel worksheet, selanjutnya dilakukan analisis keragaman (Anova) pada taraf nyata 5\% dan untuk parameter yang berbeda nyata dilakukan uji lanjut dengan Duncan's Multiple Range Test pada taraf nyata $5 \%$.

\section{HASIL DAN PEMBAHASAN \\ Kondisi Lingkungan Tumbuh dan Pola Tanam di Lokasi Percobaan}

Jenis tanah di wilayah sentra sayuran dan kentang pada umumnya adalah tanah Andisol. Berdasar hasil analisis yang telah dilakukan, diketahui bahwa sifat tanah di tiga lokasi memiliki persamaan dan perbedaan (Tabel 1). Semestinya, wilayah sentra kentang yang terletak di lereng gunung memiliki jenis tanah Andosol yang dicirikan antara lain $\mathrm{pH}$ tanah sangat masam sampai agak masam. Ciri berikutnya yaitu kandungan P-cadangan yang sangat tinggi karena, dimana P-cadangan yang sangat tinggi tersebut kurang dapat tersedia bagi tanaman karena terjerap dalam mineral lempung yang dominan terdapat pada fraksi tanah Andisol. Karakter lain tanah Andosol yaitu KPK yang tinggi, karena keberadaan bahan organik yang tinggi.

Tanah Andisol yang masih asli dan belum ditanami biasanya memiliki kandungan bahan organik tinggi atau lebih dari 5\%. Pada tanah Andisol yang sudah intensif digunakan untuk budidaya tanaman, telah mengalami degradasi bahan organik sehingga kurang dari 5\%, seperti yang ditunjukkan dari hasil analisis tanah di tiga lokasi percobaan. Hasil analisis tanah ini menunjukkan bahwa petani di tiga lokasi percobaan mengelola tanah cukup intensif sehingga beberapa sifat asli tanah Andisol sudah mulai berubah, seperti $\mathrm{pH}$ sudah tidak terlalu masam dan $\mathrm{C}$-organik menurun.

Tabel 1. Karakteristik Tanah di Lokasi Percobaan di Tiga Kabupaten Lokasi Percobaan

\begin{tabular}{llll}
\hline Sifat Tanah & Banjarnegara & Wonosobo & Pekalongan \\
\hline $\mathrm{pH}$ & 6.37 (agak masam) & 6.82 (netral) & 6.53 (agak masam) \\
C-Organik $(\%)$ & 2.57 (sedang) & 2.31 (sedang) & 2.97 (sedang) \\
N-Total $(\%)$ & 0.39 (sedang) & 0.29 (sedang) & 0.59 (tinggi) \\
P-Cadangan $(\mathrm{mg} / 100 \mathrm{~g})$ & 1251.89 (sangat tinggi) & 841.68 (sangat tinggi) & 550.97 (sangat tinggi) \\
P-tersedia $(\mathrm{ppm})$ & 437.96 (sangat tinggi) & 798.21 (sangat tinggi) & 211.22 (sangat tinggi) \\
K-Cadangan $(\mathrm{mg} / 100 \mathrm{~g})$ & 38.65 (sedang) & 24.36 (sedang) & 43.23 (tinggi) \\
KPK cmol $(+) / \mathrm{kg}$ & 51.24 (sangat tinggi) & 46.72 (sangat tinggi) & 26.82 (tinggi) \\
\hline & Sumber : Cempaka, et al. (2018) dengan modifikasi &
\end{tabular}

Tabel 2. Pola Tanam dalam Satu Tahun Kebiasaan Petani di Lokasi Percobaan

\begin{tabular}{llll}
\hline Lokasi & Musim Tanam I & Musim Tanam II & Musim Tanam III \\
\hline Wonosobo & $\begin{array}{l}\text { 1. Kubis, bunga kol, sawi putih, } \\
\text { wortel, cabai. }\end{array}$ & Kentang & Kentang \\
Banjarnegara & 1. Kentang & Kentang & $\begin{array}{l}\text { Wortel, Kubis, Bawang daun, } \\
\text { Sawi Putih, Terong, Tomat } \\
\end{array}$ \\
2. Kentang & Kentang & $\begin{array}{l}\text { Kentang } \\
\text { Sayuran lain (Bunga kol, Sawi } \\
\text { Pekalongan }\end{array}$ & 1. Wortel, Kubis, Bawang daung daun) \\
\hline
\end{tabular}


Tabel 3. Rerata tinggi tanaman $(\mathrm{cm})$ tiga varietas kentang umur $50 \mathrm{hst}$.

\begin{tabular}{lllll}
\hline \multirow{2}{*}{ Lokasi } & Varietas & \multicolumn{3}{c}{ Rerata } \\
\cline { 2 - 4 } & Tedjo-MZ & Granola L & Granola K & \\
\hline Wonosobo & 50.18 & 58.05 & 65.8 & $58.01 \mathrm{~b}$ \\
Banjarnegara & 40.25 & 43.86 & 48.14 & $44.08 \mathrm{c}$ \\
Pekalongan & 64.66 & 57.57 & 75.41 & $65.88 \mathrm{a}$ \\
\hline Rerata & $51.7 \mathrm{ab}$ & $53.16 \mathrm{ab}$ & $63.11 \mathrm{a}$ & $55.99(-)$ \\
\hline
\end{tabular}

Keterangan : (-) menunjukkan interaksi antar faktor perlakuan tidak nyata pada $\alpha=5 \%$. Angka yang diikuti huruf yang berbeda menunjukkan berbeda nyata pada $\alpha=5 \%$ berdasar Duncan's multiple range test.

Berdasarkan hasil wawancara dengan petani di lokasi kajian diketahui bahwa terdapat perbedaan pola tanam antara tiga lokasi percobaan (Tabel 2). Dari tiga lokasi tersebut teridentifikasi bahwa, petani di Banjarnegara dan di Wonosobo lebih intensif dalam menanam komoditas kentang karena kentang merupakan komoditas utama bagi petani di dua lokasi tersebut disamping jenis sayuran lainnya. Hal ini disebabkan karena nilai ekonomi kentang lebih tinggi dan lebih stabil dibanding jenis sayuran lainnya. Sehingga dalam satu tahun, petani bisa menanam kentang sebanyak dua kali, bahkan di Banjarnegara terdapat petani yang menanam kentang terus menerus sepanjang tahun. Disamping itu juga diperoleh informasi bahwa varietas kentang yang selalu ditanam oleh petani sebagian besar adalah Granola, dengan kata lain sangat jarang dilakukan rotasi varietas. Sementara itu, yang teridentifikasi di petani Pekalongan berbeda, karena kentang tidak dianggap sebagai komoditas utama. Petani di lokasi Pekalongan lebih mengutamakan jenis sayuran lainnya menjadi komoditas utama, seperti daun bawang, kubis, wortel, dan bunga kol. Perbedaan ini akan sangat berpengaruh terhadap kondisi lingkungan tumbuh, terutama intensitas hama dan penyakit yang ada di lokasi. Menurut (van Loon and Hammink 2020), jika tanaman kentang ditanam di lahan yang sama berturut- turut tanpa ada jeda dengan tanaman lain, maka hasil dan kualitas hasil umbi yang dihasilkan akan menurun atau tidak maksimal. Hal ini utamanya disebabkan karena hampir semua hama dan penyakit menular melalui tanah.

\section{Pertumbuhan Tiga Varietas Kentang di Tiga Lokasi}

Hasil penelitian di tiga lokasi menunjukkan bahwa rerata pertumbuhan tiga varietas yang dikaji tidak menunjukkan adanya interaksi antara varietas dengan lokasi baik pada parameter tinggi tanaman, jumlah cabang ataupun diameter batang (Tabel 3, 4, 5). Namun perbedaan nyata ditunjukkan antar lokasi percobaan pada parameter tinggi tanaman dan diameter batang, yaitu rerata tinggi tanaman nyata lebih tinggi dan diameter batang nyata lebih besar di lokasi Pekalongan dibanding di lokasi Banjarnegara dan Wonosobo (Tabel 3, 5). Hasil pengamatan juga menunjukkan bahwa tiga parameter pertumbuhan tersebut tidak berbeda nyata antar varietas pada umur 50 hst. Hal ini menunjukkan perbedaan lingkungan tumbuh memberikan pengaruh yang lebih kuat daripada faktor genetis, dalam hal ini lokasi di Pekalongan menunjukkan pertumbuhan yang lebih maksimal dibanding di Banjarnegara dan Wonosobo. Hal ini diduga berkaitan dengan kondisi kesehatan lahan di Pekalongan yang 
lebih baik karena kentang hanya ditanam satu kali dalam satu tahun, sementara di
Wonosobo dua kali dan di Banjarnegara dua sampai tiga kali dalam satu tahun.

Tabel 4. Rerata jumlah cabang per rumpun tiga varietas kentang umur $50 \mathrm{hst}$

\begin{tabular}{lllll}
\hline \multirow{2}{*}{ Lokasi } & Varietas & & & \\
\cline { 2 - 5 } & Tedjo-MZ & Granola L & Granola K & Rerata \\
\hline Wonosobo & 4.71 & 3.64 & 4.37 & $4.24 \mathrm{a}$ \\
Banjarnegara & 3.56 & 1.52 & 3.17 & $2.75 \mathrm{a}$ \\
Pekalongan & 6.68 & 2.56 & 4.36 & $4.53 \mathrm{a}$ \\
\hline Rerata & $4.98^{\mathrm{a}}$ & $2.57^{\mathrm{a}}$ & $3.97^{\mathrm{a}}$ & $3.84(-)$ \\
\hline
\end{tabular}

Keterangan : (-) menunjukkan tidak ada interaksi antara faktor perlakuan pada $\alpha=5 \%$.

Angka yang diikuti huruf yang berbeda menunjukkan berbeda nyata pada $\alpha=5 \%$ berdasar Duncan's multiple range test.

Tabel 5. Rerata diameter batang $(\mathrm{mm})$ tiga varietas kentang umur 50 hst.

\begin{tabular}{ccccc}
\hline \multirow{2}{*}{ Lokasi } & \multicolumn{4}{c}{ Varietas } \\
\cline { 2 - 5 } & Tedjo-MZ & Granola L & Granola K & Rerata \\
\hline Wonosobo & 8.76 & 9.84 & 7.92 & $8.84 \mathrm{~b}$ \\
Banjarnegara & 9.28 & 8.22 & 8.83 & $8.78 \mathrm{~b}$ \\
Pekalongan & 11.95 & 9.94 & 10.55 & $10.81 \mathrm{a}$ \\
\hline Rerata & $9.99^{\mathrm{a}}$ & $9.33^{\mathrm{a}}$ & $9.1^{\mathrm{a}}$ & $9.48(-)$ \\
\hline
\end{tabular}

Keterangan : (-) menunjukkan tidak ada interaksi antara faktor perlakuan pada $\alpha=5 \%$.

Angka yang diikuti huruf yang berbeda menunjukkan berbeda nyata pada $\alpha=5 \%$

berdasar Duncan's multiple range test.

Tabel 6. Komponen hasil umbi kentang tiga varietas kentang umur panen

\begin{tabular}{|c|c|c|c|c|c|c|}
\hline \multirow{2}{*}{$\begin{array}{l}\text { Perlakuan } \\
\text { Wonosobo }\end{array}$} & \multicolumn{2}{|c|}{ Bobot segar umbi / tanaman (g) } & \multicolumn{2}{|c|}{$\begin{array}{l}\text { Jumlah umbi } \\
\text { tanaman (butir) }\end{array}$} & \multicolumn{2}{|c|}{$\begin{array}{l}\text { Bobot Satuan Umbi } \\
(\mathrm{g})\end{array}$} \\
\hline & 1438 & $\mathrm{~b}$ & 14 & $\mathrm{a}$ & 102.71 & $a b$ \\
\hline Banjarnegara & 1050 & $\mathrm{~b}$ & 9 & $\mathrm{~b}$ & 116.67 & $\mathrm{ab}$ \\
\hline Pekalongan & 2440 & $\mathrm{a}$ & 16 & $\mathrm{a}$ & 152.50 & $\mathrm{a}$ \\
\hline Rerata & 1643 & & 13 & & 124 & \\
\hline Tedjo MZ & 2018 & $\mathrm{a}$ & 13 & $\mathrm{a}$ & 155.23 & $\mathrm{a}$ \\
\hline Granola L & 1077 & $\mathrm{~b}$ & 13 & $\mathrm{a}$ & 82.85 & $\mathrm{~b}$ \\
\hline Granola K & 1253 & $\mathrm{~b}$ & 12 & $\mathrm{a}$ & 104.42 & $\mathrm{ab}$ \\
\hline Rerata & 1449 & & 13 & & 114 & \\
\hline
\end{tabular}

Keterangan : Angka yang diikuti huruf yang berbeda menunjukkan berbeda nyata pada $\alpha=5 \%$ berdasar Duncan's multiple range test. 


\begin{tabular}{ccccc}
\hline \multicolumn{5}{c}{ Tabel 7. Rerata produktivitas umbi (t/ha) tiga varietas kentang } \\
\hline \multirow{2}{*}{ Lokasi } & Tedjo-MZ & Granola L & Granola K & Rerata \\
\cline { 2 - 5 } & 29.6 & 23.66 & 30.89 & $28.05 \mathrm{~b}$ \\
Wonosobo & 22.15 & 17.64 & 21.68 & $20.49 \mathrm{~b}$ \\
Banjarnegara & 58.84 & 41.95 & 41.97 & $47.59 \mathrm{a}$ \\
Pekalongan & 36.86 a & $27.75 \mathrm{~b}$ & 31.51 a & $32.04(-)$ \\
\hline Rerata & Keterangan : (-) menunjukkan tidak ada interaksi antara faktor perlakuan pada $\alpha=5 \%$. \\
\multicolumn{4}{c}{ Angka yang diikuti huruf yang berbeda menunjukkan berbeda nyata pada $\alpha=5 \%$} \\
\multicolumn{5}{c}{ berdasar Duncan's multiple range test. }
\end{tabular}

\section{Komponen Hasil dan Produktivitas Kentang di Tiga Lokasi Percobaan}

Dari hasil pengamatan parameter komponen hasil tanaman kentang yaitu bobot segar umbi, jumlah umbi dan bobot satuan umbi diketahui bahwa tidak terdapat interaksi nyata antara varietas dengan lokasi percobaan. Namun demikian, terdapat perbedaan nyata antar lokasi percobaan pada parameter bobot segar umbi dan jumlah umbi pertanaman, dan antar varietas pada parameter bobot segar umbi dan bobot satuan umbi. Pada semua parameter, lokasi di Pekalongan menunjukkan hasil yang lebih tinggi meskipun tidak nyata berbeda pada bobot satuan umbi dengan lokasi di Wonosobo dan Banjarnegara. Sementara itu antar varietas terlihat bahwa Tedjo MZ nyata menghasilkan bobot segar umbi lebih banyak dibanding Granola L dan Granola K, meskipun jumlah umbi per tanaman tidak berbeda nyata, dan bobot satuan umbi TedjoMZ nyata lebih berat hanya dengan Granola L.

Hasil perhitungan produktivitas umbi kentang per hektar diperoleh bahwa tidak terdapat interaksi nyata antara lokasi percobaan dengan varietas yang dikaji, namun terdapat perbedaan nyata antara lokasi percobaan yaitu lokasi Pekalongan menunjukkan produktivitas yang nyata lebih tinggi dibanding di lokasi Wonosobo dan Banjarnegara (Tabel 7). Demikian halnya antar varietas, juga terdapat perbedaan nyata yaitu produktivitas umbi Tedjo-MZ tidak berbeda nyata dengan Granola $\mathrm{K}$ namun keduanya nyata lebih tinggi dibanding produktivitas umbi Granola L.

Dari hasil pengamatan komponen hasil dan produktivitas umbi kentang di atas, diperoleh informasi bahwa komponen hasil kentang dan produktivitasnya menunjukkan hasil yang sejalan dengan parameter pertumbuhan yang diamati, yaitu bahwa semakin optimal pertumbuhan tanaman makan komponen hasil umbi yang dihasilkan semakin maksimal. Pada percobaan ini pertumbuhan tanaman di lokasi Pekalongan lebih optimal dibanding di lokasi Wonosobo dan Banjarnegara. Lebih optimalnya pertumbuhan tanaman di lokasi Pekalongan diduga berkorelasi kuat dengan pola tanam yang dilakukan petani dalam setahun, utamanya hanya menanam kentang satu kali dalam setahun yaitu pada musim ke-2 sekitar bulan April - Juli dan pada musim tanam ke1 dan ke-3, ditanam sayuran lainnya. Meskipun pada penelitian ini belum dilakukan pengamatan dan analisa lebih lanjut tentang korelasi antara pola tanam dengan pertumbuhan dan produktivitas umbi kentang, namun beberapa hasil penelitian lain mengkonfirmasi bahwa pola tanam atau rotasi tanaman memberikan pengaruh nyata terhadap produktivitas suatu tanaman. Hasil penelitian Prihastuti (2011) dan Silva et al. 
(2013) menjelaskan bahwa rotasi tanaman akan meningkatkan keragaman jenis dan populasi mikroorganisme tanah, sehingga menguntungkan bagi keberlanjutan usahatani di wilayah tersebut. Makarim, et.al. (2017) Juga melaporkan bahwa rotasi tanaman memberikan dampak baik terhadap kesuburan lahan, produktivitas dan produksi tanaman maupun peningkatan pendapatan dan pengurangan infestasi hama-penyakit tanaman, sehingga usahatani terus berlanjut dan menguntungkan petani.

\section{SIMPULAN DAN SARAN}

Pertumbuhan dan hasil umbi kentang tiga varietas yang dikaji (Tedjo-MZ, Granola L dan Granola K) dipengaruhi oleh perbedaan kondisi lingkungan tumbuh yaitu pola tanam yang biasa dilakukan oleh petani. Di lokasi Pekalongan dengan pola tanam kentang satu kali per tahun, pertumbuhan lebih optimal dan hasil umbi yang diperoleh nyata lebih besar dibanding di lokasi Wonosobo dengan pola tanam kentang dua kali setahun dan Banjarnegara dengan pola tanam dua sampai tiga kali setahun. Semakin bervariasi jenis tanaman yang diusahakan dalam satu tahun mempengaruhi keragaman mikrobiologi tanah dan memutus siklus hidup hama dan penyakit tertentu, sehingga usaha tani di lokasi tersebut keberlanjutannya lebih terjamin.

\section{PUSTAKA ACUAN}

BPS. (2012). Produksi Kentang Menurut Provinsi 2008 - 2012. Vol. 2012.

Cempaka, Intan Gilang, Miranti Dian Pertiwi, and Hairil Anwar. (2018). "Assessment of Cultivation Systems and Productivity of Tedjo MZ Potato on Dry Season." In International Symposia on Horticulture, Denpasar. Bali. 388-392.

Chen, Gang, Suping Wang, Xiang Huang, Juan Hong, Lei Du, Lihong Zhang, and
Lixia Ye. (2015). Environmental Factors Affecting Growth and Development of Banlangen (Radix Isatidis) in China. African Journal of Plant Science 9 (November): 421-26. https://doi.org/10.5897/AJPS2015.

Hamdani, Jajang Sauman. (2009). Pengaruh Jenis Mulsa Terhadap Pertumbuhan Dan Hasil Tiga Kultivar Kentang (Solanum Tuberosum L .) Yang Ditanam Di Dataran Medium. Jurnal Agronomi Indonesia 37 (1): 14-20.

Londhe, Sunil. (2016). Sustainable Potato Production and the Impact of Climate Change. 1st ed. United States of America: IGI Global.

Loon, Kees van, and Han Hammink. (2020). Sinyal Tanaman Kentang. Panduan Praktis Budidaya Kentang Yang Baik. Edited by Nikadi Gunadi, Budi Prasetya, Annette Pronk, Huub Scheppers, and Sicko de Vries. Belanda: Roodbont.

Lutaladio, NeBambi, Oscar Ortiz, Anton Haverkort, and Daniel Caldiz. (2009). Sustainable Potato Production. Guidelines for Developing Countries. FAO.

Makarim, Abdul Karim, Ikhwani, and Made Jana Mejaya. (2017). Rasionalisasi Pola Rotasi Tanaman Pangan Berbasis Ketersediaan Air Rat. Iptek Tanaman Pangan 12 (2): 83-90.

Prabaningrum, Laksminiwati, Tonny K. Moekasan, Ineu Sulastrini, Tri Handayani, Juniarti P. Sahat, Eri Sofiari, and Nikardi Gunadi. (2014). Teknologi Budidaya Kentang Di Dataran Medium.

Prihastuti. (2011). Struktur Komunitas Mikroba Tanah Dan Implikasinya Dalam Mewujudkan Sistem Pertanian Berkelanjutan. El-Hayah 1 (4): 174-81.

Pusat Data dan Sistem Informasi Pertanian. (2015). Statistik Konsumsi Pangan Tahun 2015. Jakarta. 
Silva, A P, L C Babujia, L S Matsumoto, M F Guimarães, and M Hungria. (2013). Bacterial Diversity Under Different Tillage and Crop Rotation Systems in an Oxisol of Southern Brazil. The Open Agriculture Journal 7 (Suppl 1-M6): 40-
47.

Subhan dan A.A. Asandhi. (1988). Waktu Aplikasi Nitrogen dan Penggunaan Kompos dalam Budidaya Kentang di Dataran Medium. J. Hort.8(2):10721077

\section{DOI :}

